\title{
Performance of perisel as shelter and periphyton substrate in the floating cage of Pacific white shrimp culture
}

\section{Kinerja perisel sebagai selter dan substrat penumbuh perifiton pada budidaya udang vaname di karamba jaring apung}

\author{
Rifka Liling Palinggi ${ }^{* *}$, Tatag Budiardi ${ }^{1}$, Daniel Djokosetiyanto ${ }^{1}$ \\ 'Department of Aquaculture, Faculty of Fisheries and Marine Science, IPB University, \\ Bogor, West Java 16680 \\ *Correspondence : lilingpalinggi88@gmail.com
}

(Received March 9, 2017; Accepted November 5, 2020)

\begin{abstract}
Shrimp culture in the floating cage is expected to reduce the utilization of land and its possible negative impact to the environment. The advantages of shrimp farming in the sea include the high dissolved oxygen concentration and the better meat quality. This research aimed to enhance the production performance of shrimp through the utilization of periphyton as a natural feed for shrimp. A completely randomized design with 3 treatments (in triplicates) were applied in this experiment, i.e floating cage without perishel (control), floating cage with PE perishel and PA perishel. Shrimp with body weight of $2.5 \pm 0.2 \mathrm{~g}$ were stocked at the initial density of 2,000 shrimp in each cage, and maintained for 90 days. No significant difference was observed in the survival amongst treatments. The lowest feed conversion ratio (1.74) and coefficient of variance (3.21) were showed in treatment PA. The highest attachment and abundances of periphyton were found in treatment PA. It was concluded that the addition of perishel inside the floating cage may contribute as natural feed source for the shrimp and thus increase the production performance of shrimp.
\end{abstract}

Keywords: floating cage, Litopenaeus vannamei, periphyton, perisel, shelter

\begin{abstract}
ABSTRAK
Budidaya udang di KJA diharapkan dapat menekan isu pemanfaatan daratan sebagai tambak yang berdampak pada permasalahan lingkungan. Keunggulan laut untuk budidaya udang, antara lain adalah kadar oksigen terlarut relatif tinggi sehingga tidak perlu kincir, dan mutu daging udang yang dihasilkan relatif lebih baik. Penelitian ini ditujukan untuk meningkatkan kinerja produksi dan memanfaatkan kesuburan perairan laut berupa perifiton sebagai pakan alami bagi udang. Penelitian ini terdiri atas tiga perlakuan, yakni: (A) kontrol (tanpa perishel), (B) jaring benang nilon (PE), dan (C) jaring benang serabut pendek (PA 6.6), masing-masing perlakuan terdiri dari tiga ulangan. Udang dengan bobot $2,5 \pm 0,2 \mathrm{~g}$ ditebar sebanyak 2.000 ekor perwadah, dan dipelihara selama 90 hari. Hasil analisis kinerja produksi menunjukkan bahwa kelangsungan hidup tidak berbeda nyata antarperlakuan. Nilai konversi pakan terendah diperoleh pada perlakuan jaring benang PA dengan nilai 1,74. Nilai koefisien keragaman terendah diperoleh pada perlakuan jaring benang PA dengan nilai 3,21. Penempelan dan kepadatan perifiton yang cukup baik diperoleh pada jenis perishel jaring benang serabut pendek PA. Dengan demikian dapat disimpulkan bahwa dengan penambahan perishel sebagai shelter dan penumbuh perifiton diperoleh hasil produksi yang baik. Udang dapat memanfaatkan keberadaan perishel dalam wadah pemeliharaan sebagai tempat berlindung dan memperoleh makanan tambahan berupa pakan alami yang menempel pada perishel.
\end{abstract}

Kata kunci: karamba jaring apung, perifiton, perisel, selter, udang vaname 


\section{INTRODUCTION}

Pacific white shrimp has been considered as high valuable export commodity from Indonesia fishery product (the second largest of shrimp exporter after China), contributing to $11.34 \%$ of world fishery trade (FAO, 2015). Shrimpderived products have high quality in term of taste and protein content. Fry of white shrimp from Indonesia have been considered as specific pathogen free and as well as lower production cost than tiger shrimp, thus promising high potential in the future market (Lebel et al., 2010). The use of coastal area for shrimp culture needs to be improved. According to biological feasibility evaluation, shrimp farm using floating cage was deemed as productive activity in Mexico (ZarainHerzberg et al., 2006). This technique is expected to reduce the utilization of land and its possible negative impact to the environment (SanchezJerez et al., 2016; Lester et al., 2018).

Coastal area has many advantageous characteristics for shrimp culture such as high dissolved oxygen and stability, as well as yielding high quality shrimp meat (Kasnir et al., 2014, Maicá et al., 2014), and producing low accumulation of solid waste around floating cage (Almuqaramah et al., 2018). Currently, several obstacles were observed for application of floating cage for shrimp culture. Low growth and survival rate in high density shrimp culture may result from combined factors such as space utilization, feed efficiency, presence of cannibalism (especially during molting), degradation of water quality from sediment accumulation.

Periphyton is one the nutritional sources for aquatic organism. White shrimp was reported to show feed retention of $17 \%$ used for meat production, while the rest was released as unconsumed feeds and metabolite that are accumulated in the sea water (Avnimelech, 2007). Periphyton shows several functions such as providing alternative feed with high nutritional content, stimulating non-specific immune system of shrimp larvae. High periphyton availability in nature is expected to result in high commercial feed efficiency and reduce cannibalism (Pandey et al., 2014). Periphyton-assisted aquaculture is applicable, but periphyton production was low due to limited attachment substrate. Beneficial effects of artificial substrate (perishel) for shrimp growth may show differences in some aspects including improvement of water quality, addition of natural feed supplement, and limited reproduction ability of pathogen bacteria. As shelter may provide protection against cannibalism during molting, and new space (Zarain-Herzberg et al., 2006). This research aimed to observe effects of perishel as periphyton substrate and shelter on shrimp culture performance in floating cage.

\section{MATERIALS AND METHOD}

\section{Experimental setup}

The experiment was conducted in Sendang bay, Pemuteran, North Bali during April-June 2016. A completely randomized design with 3 treatments (in triplicates) were applied in this experiment, i.e floating cage without perishel (control), floating cage with $\mathrm{PE} /$ polyethylene perishel and PA/polyamide perishel. A total of 9 floating cages made of wood were used. Each cage was covered by layers $(3 \mathrm{~m} \times 3 \mathrm{~m} \times 3 \mathrm{~m})$ with mesh size $5 \mathrm{~mm}$ and $7 \mathrm{~mm}$. The cage was covered by net at the top to reduce light and protect against predators, and supported by PVC tubes in the bottom for ballast. Perishel $(1 \mathrm{~m} \times 1 \mathrm{~m} \times$ $2 \mathrm{~m})$ was combination of periphyton substrate and shelter seems like apartment 4 layers: PE (mesh size $5 \mathrm{~mm}$ ) and PA (mesh size $7 \mathrm{~mm}$ ). Feeding tray was set in the center of cage. A perishel was horizontally set in each cage, and submerged for 5 days before experiment to produce biofilm layers (Burford et al., 2004).

\section{Shrimp culture}

Shrimp Litopenaeus vannamei (average weight of $2.5 \pm 0.2 \mathrm{~g}$ ) was obtained from PT TOP Bali at salinity of $32 \mathrm{mg} / \mathrm{L}$ with culture of 35 days. The shrimp was selected for its size and health status (visual, SPF and SPR). Adaptation was performed in floating cage in Pemuteran. Shrimp (density of 200 individuals $/ \mathrm{m}^{2}$ or 2000 individuals/cage) was culture for 90 days. Determination of water quality, feeding, periphyton, and shrimp sampling, and net substitution were carried out during culture. Feeding with commercial pellet (protein 40\%) was conducted at 5 times a day $(07.00,10.00$, $14.00,18.00$ and 22.00 WITA). Water quality (temperature, $\mathrm{pH}$, salinity, DO, lightness) was daily determined in situ at 07.00 and 22.00, while determination of alkalinity, ammonia, nitrite and nitrate was performed each 10 days.

\section{Data analysis}

Growth performance were evaluated using Microsoft Office Excel 2010 and analysis of variance (ANOVA) using SPSS 22 at significance 
level of 0.05 . The significance of variance was then verified by Tukey test. Periphyton density, shrimp glucose haemolymph and water quality were analyzed descriptively (Apún-Molina et al., 2015; Novianti et al., 2016; Arsad et al., 2019; Martínez-Antonio et al., 2019).

\section{RESULTS AND DISCUSSION}

\section{Results}

Table 1 exhibits growth performance of shrimp, including survival rate (SR), average daily growth (ADG), specific grow rate (SGR), feed conversion ratio (FCR), coefficient of variance $(\mathrm{CV})$, and production. Data revealed that SR, ADG, SGR, and production showed no significant difference $(\mathrm{P}>0.05)$. FCR and $\mathrm{CV}$ with perishel treatment showed lower compared with the control $(\mathrm{P}<0.05)$. Figure 1 displays periphyton density pattern in two types of perishel. Perishel PA showed higher production in comparison with perishel PE.

Determination of glucose haemolymph was to understand stress condition, and performed in day-0, day-1, day-45, and day-90. High glucose haemolymph was detected in the initial period of culture, and it showed a decrease in the middle of period. However, there was an increase of glucose haemolymph in the end of experiment. Table 2 exhibits that water quality (temperature, salinity, $\mathrm{pH}$, DO, lightness, alkalinity, ammonia, nitrite and nitrate) is in acceptable condition for shrimp culture.

\section{Discussion}

Survival rate (SR) is a major parameter of an aquaculture, and its high value is meaningful for production successful. Table 1 showed that SR was insignificant, ranging from $67.47 \%$ until $69.98 \%$, that was lower than results observed by Zarain-Herzberg et al . (2006). Their work was able to attempt SR of $81.2 \%$ until $94 \%$ using similar density of 200 individuals $/ \mathrm{m}^{2}$ with artificial substrate. SR of white shrimp was $80 \%$ until $85 \%$ intensive culture in pond (Ditjen Budidaya 2016). Our data suggest that perisel seems to be uneffective to improve SR, which is linked with limited shrimp distribution and shrimp accumulation in the bottom.

Table 1. Growth performance of shrimp maintained in floating cage for 90 days

\begin{tabular}{cccc}
\hline Parameters & \multicolumn{3}{c}{ Treatments } \\
\cline { 2 - 4 } & Control & PE & PA \\
\hline Survival rate $(\%)$ & $67.47 \pm 2.73^{\mathrm{a}}$ & $69.22 \pm 1.81^{\mathrm{a}}$ & $69.98 \pm 1.19^{\mathrm{a}}$ \\
Average daily growth (g/day) & $0.19 \pm 0.01^{\mathrm{a}}$ & $0.20 \pm 0.01^{\mathrm{a}}$ & $0.20 \pm 0.01^{\mathrm{a}}$ \\
Specific growth rate (\%/day) & $2.40 \pm 0.04^{\mathrm{a}}$ & $2.41 \pm 0.04^{\mathrm{a}}$ & $2.44 \pm 0.04^{\mathrm{a}}$ \\
Feed conversion ratio & $1.98 \pm 0.06^{\mathrm{b}}$ & $1.81 \pm 0.02^{\mathrm{a}}$ & $1.74 \pm 0.11^{\mathrm{a}}$ \\
Coefficient of variance $(\%)$ & $3.57 \pm 0.13^{\mathrm{b}}$ & $3.30 \pm 0.11^{\mathrm{ab}}$ & $3.21 \pm 0.11^{\mathrm{a}}$ \\
Production $\left(\mathrm{kg} / \mathrm{m}^{2}\right)$ & $2.74 \pm 1.81^{\mathrm{a}}$ & $2.85 \pm 1.40^{\mathrm{a}}$ & $2.93 \pm 1.12^{\mathrm{a}}$ \\
\hline
\end{tabular}

Different superscripts letters in the same row indicate significant difference $(\mathrm{P}<0.05)$.

Table 2. Water quality (temperature, salinity, pH, DO, lightness, alkalinity, ammonia, nitrite, and nitrate) of shrimp culture in floating cage for 90 days

\begin{tabular}{|c|c|c|c|}
\hline \multirow{2}{*}{ Parameters } & \multicolumn{2}{|c|}{ Value range } & \multirow{2}{*}{ Optimum value } \\
\hline & 07.00 & 22.00 & \\
\hline Temperature $\left({ }^{\circ} \mathrm{C}\right)$ & $30-31$ & $30-31$ & 28-30 (Sudaryono et al., 2018) \\
\hline Salinity (g/L) & $31-34$ & $30-35$ & 32-33 (Sudaryono et al., 2018) \\
\hline $\mathrm{pH}$ & $7.5-8.2$ & $7.4-8.3$ & 6-9 (Ferreira et al., 2015) \\
\hline $\mathrm{DO}(\mathrm{mg} / \mathrm{L})$ & $4.1-4.9$ & $4.0-5.3$ & > 3 (Ferreira et al., 2015 \\
\hline Lightness (m) & \multicolumn{2}{|c|}{$8-15$} & > 5 (Effendi, 2016) \\
\hline Alkalinity (mg/L) & \multicolumn{2}{|c|}{116} & 50-300 (Furtado et al., 2015) \\
\hline Ammonia (mg/L) & \multicolumn{2}{|c|}{$0.00-0.17$} & $<0.2($ Ferreira et al., 2015) \\
\hline Nitrite (mg/L) & \multicolumn{2}{|c|}{$0.014-0.016$} & $<0.2($ Ferreira et al., 2015) \\
\hline Nitrate (mg/L) & \multicolumn{2}{|c|}{$0.117-0.561$} & $<0.7$ (Ferreira et al., 2015) \\
\hline
\end{tabular}


Growth is also an important parameter, and influenced by density, space availability, amount of feed, feed quality, and water quality. Average daily growth (ADG) and specific growth rate (SGR) showed insignifcant difference $(\mathrm{P}>0.05)$. We found that daily growth was $0.20 \mathrm{~g} /$ day in perishel treatment, which was almost similar to result reported by Zarain-Herzberg et al . (2006), but higher than result reported by Fendjalang $e t$ al. (2016), namely $0.11 \mathrm{~g} /$ day. Similar growth rate in all our treatments indicated that feeding and water quality were acceptable for shrimp growth. The bay provided more beneficial condition than strait as conducted by Fendjalang et al. (2016). Generally, strait has strong water wave, thus shrimp need more energy for their survival.

Feed conversion ration (FCR) is defined as feed ( $\mathrm{kg})$ converted to produce $1 \mathrm{~kg}$ of fish biomass (Fry et al, 2018; Rana, 2018). Higher FCR means that higher amount of feed required to production $1 \mathrm{~kg}$ of shrimp meat (Sudaryono et al., 2013). Statistical analysis revealed that perisel showed significant effects $(\mathrm{P}<0.05)$ on $\mathrm{FCR}, 1.98$ for control, 1.81 for perisel PE, and 1.71 for perisel PA. These FCR values were higher in comparison with values obtained from shrimp culture in pond (1.3). The lowest FCR was attributed to perisel PA6.6. Our visual observation showed that vannamei shrimp was responsive to biofouling attatched in perisel, that is able to used as source of additional feed.

Coefficient of variance $(\mathrm{CV})$ represents the degree of shrimp weight similarty in the end of culture. Higher $\mathrm{CV}$ is attributed to lower weight variance. Low $\mathrm{CV}$ was more desirable, which means degree of shrimp weight variance in the same cage. CV was affected by amount of feed, feed quality, and feed utilization. We found that $\mathrm{CV}$ of shrimp was 3.57 (control), 3.30 (perisel $\mathrm{PE}$ ), and 3.21 (perisel PA). Our experiment revealed that perisel significantly affected $\mathrm{CV}$ $(p<0.05)$. Presence of perishel is meaningful for shrimp as source of additional feed and higher space availability. Luan et al. (2020) reported that the coefficient of variance of body weight were lower under the ad libitum regime than the restricted regime. The competition for food under the restricted regime was definitely higher amongst individuals in the same environment. It was presumably caused by the limited amount of feed and space. The existance of perishel added the feed source besides the actual feed so that the perishel PA treatment obtained lower CV.

High production was expected to provide profitable shrimp culture. Table 1 exhibited that yield was not different in all treatments. The yield was 2.74 (control), 2.85 (perisel PE), and 2.93 (perisel PA). Low production level in our research was a consequence of low SR. The shrimp death was calculated by counting the living shrimp in the end of culture period. However, we also observed loss shrimp during culture. The shrimp death mostly occurred when shrimp weight was at $10 \mathrm{~g}$ /individual.

Periphyton is inexpensive feed source, easy to produce, and consumable for all stages of shrimp. In larvae stages, shrimp consumed diatom, algae filament, sea grass, zooplankton, small mollusc, small shrimp, polychaeta, other invertebrata, and detritus aggregate (Ekawati et al., 2013; Kawamura et al., 2017). Periphyton technology for reduction of FCR for shrimp culture in pond

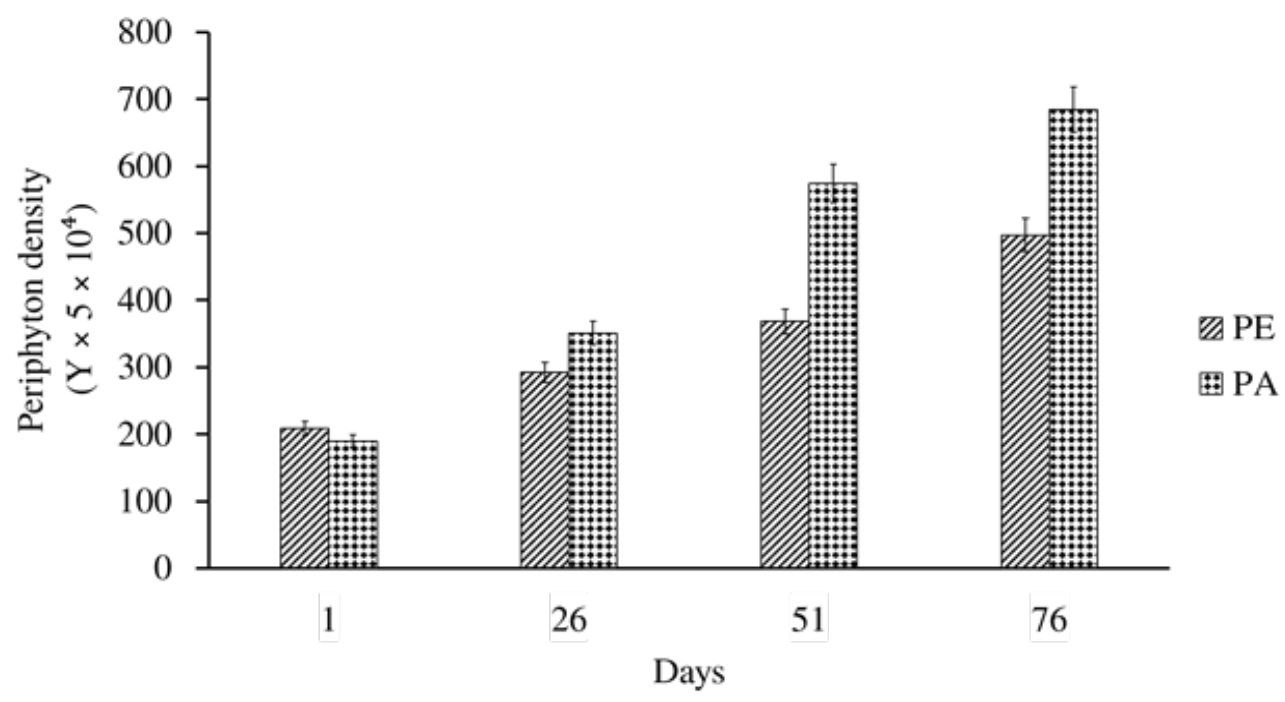

Figure 1. Periphyton density in two types of perishel (PA and PE) during 90 days of culture in floating cage. 
has been widely applied and showed desirable results (Haque et al., 2016; Jhaa et al., 2018; Kumar et al., 2015). In our experiment, we made perisel to help production of periphyton, leading to growth of biofouling and production of natural feed for shrimp. Figure 1 exhibited that high periphyton density was observed in perisel PA. Perisel PA resulted in lower FCR and CC than control and perisel $\mathrm{PE}$, indicating that shrimp was able to utilize periphyton available in perisel surface. Perisel PA with coarse surface seems to be more acceptable for periphyton growth than perisel PE with glossy surface.

Similar to other animals, intolerable changes in enviromental condition may also induce stress condition for crustaceae (Shields et al., 2019; Yusran et al., 2021). Stress condition is responsible for changes in physiological condition and immune system. Glucose haemolymph is an indicator of stress occurrence (Stoner, 2012; Jayasree et al., 2017). Glucose plays important role in regulating homeostasis condition through utilization of energy from glicolysis regulated by crustacean hyperglycemic hormone (Nagai et al., 2011; Wang et al., 2016; Zhang et al., 2019). Wang et al. (2019) and Zhao et al. (2020) found that shrimp with stress condition had high glucose haemolymph and total hepatopancreatic lipid levels. In our experiment, level of glucose haemolymph was high in the initial period, but it tend to decrease in day-50 and increase in the end of experimental period (Figure 2).

Presence of stress may resulted from extreme changes of environmental condition (from nursery pond to floating cage) and small shrimp size. In addition, physical disturbance during transportation is also responsible for inducing stress (Masud et al., 2019). At day-50, glucose haemolymph was decreased (61.01 until 71.35 $\mathrm{mg} / \mathrm{dL}$ ), almost similar to value in the initial stage of culture (before transferring into cage). Decreased glucose level indicated that shrimp was able to adapt with new environment. During grow out experiment, shrimp is able to use perisel as shelter for protection (during molting phase) and provide wider space. However, improper shrimp distribution leads to cannibalism. In the end of culture, blood glucose levels were slightly increased $(100 \mathrm{mg} / \mathrm{dL})$, caused by physical factors of water such as jelly fish blooming and high intensity raining.

Water condition that is similar to natural habitat is an important factor for shrimp culture in coastal area. Effect of natural factors is fundamental, although these factors are uncontrollable. To deal with this situation, fry was stocked in nursery cages until juvenile reached 2.5 g/individual, as conducted by Zarain-Herzberg et al. (2006) and Zarain-Herzberg et al. (2010). As presented in Table 2, water quality included temperature, salinity, pH, DO, lightness, alkalinity, ammonia, nitrite, and nitrate. Our data demonstrated that all these parameters were in optimum range for shrimp culture.

\section{CONCLUSION}

Our data demonstrated that the use of perishel for white shrimp culture in floating net cage was beneficial as substrate for periphyton

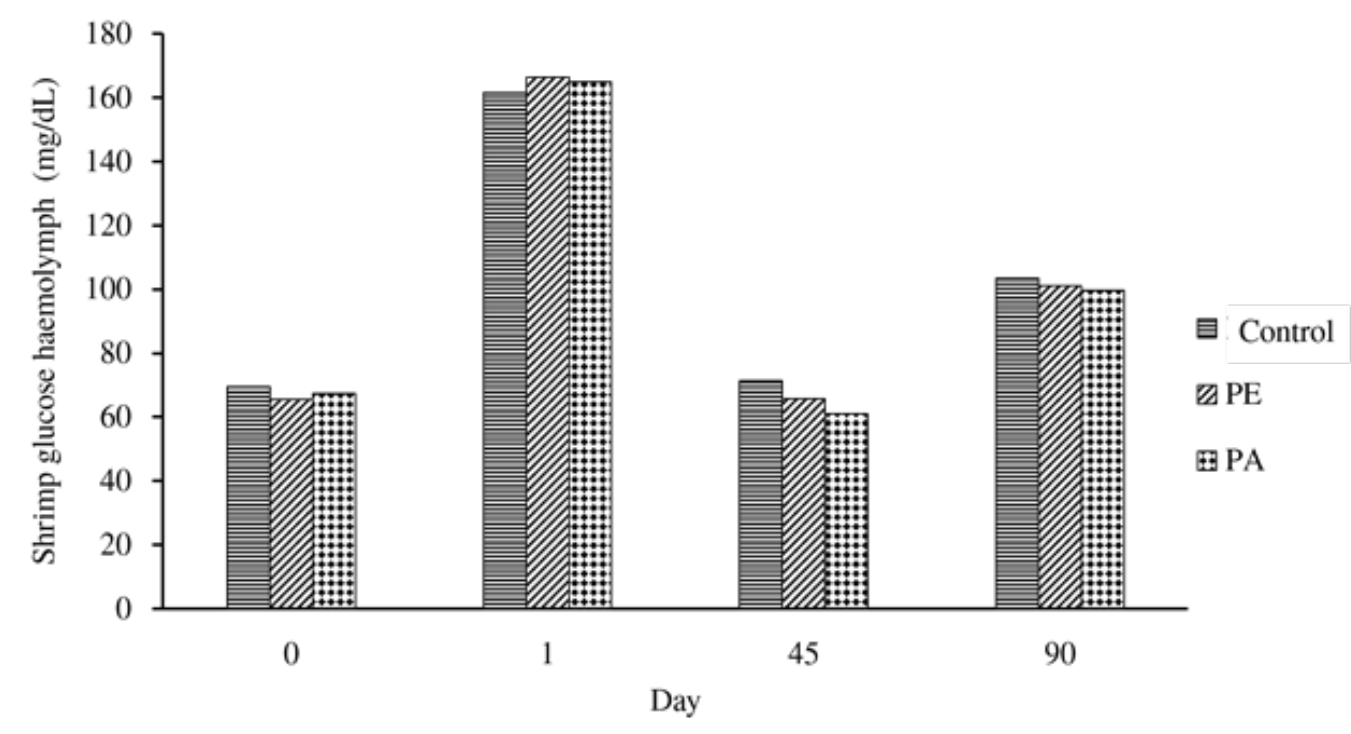

Figure 2. Shrimp glucose haemolymph measured at day-0, day-1, day-45, and day-90. 
and shelter, especially perishel PA. Perishel was also meaningful for providing natural feed for shrimp thus improving feed efficiency and growth, contributing to maximum production performance.

\section{REFERENCES}

Almuqaramah TMH, Setiawati M, Priyoutomo NB, Effendi I. 2018. The nursery of white shrimp Litopenaeus vannamei with biofloc technology (BFT) to increase the growth and feed efficiency. Jurnal Ilmu dan Teknologi Kelautan Tropis 10: 143-152.

Apún-Molina JP, Santamaría-Miranda A, LunaGonzález A, Ibarra-Gámez JC, MedinaAlcantar V, Racotta I. 2015. Growth and metabolic responses of whiteleg shrimp Litopenaeus vannamei and Nile tilapia Oreochromis niloticus in polyculture fed with potential probiotic microorganisms on different schedules. Latin American Journal of Aquatic Research 43: 435-445.

Arsad S, Zsalzsabil NAN, Prasetiya FS, Safitri I, Saputra DK, Musa M. 2019. Microalga peryphyton community on different substrates and its role as aquatic environmental bioindicator. SAINTEK PERIKANAN: Indonesian Journal of Fisheries Science and Technology 15: 73-79.

Avnimelech Y. 2007. Feeding with Microbial Flocs by Tilapia in Minimal Discharge Bioflocs Technology Ponds. Aquaculture 264: 140-147

Burford MA, Sellars, MJ, Arnold SJ, Keys SJ, Crocos PJ, Preston NP. 2004. Contribution of the natural biota associated with substrates to the nutritional requirements of the post-larval shrimp, Penaeus esculentus (Haswell) in high density rearing systems. Aquaculture Research 35: 508-515.

DJPB KKP RI. 2016. Data Statistik Perikanan Nasional. Jakarta

Effendi H. 2016. Telaah Kualitas Air bagi Pengelolaan Sumber Daya dan Lingkungan Perairan. Yogyakarta: Penerbit Kanisisus.

Ekawati AW, Nursyam H, Widjayanto E, Marsoedi. 2013. Chaetoceros ceratosporum Diatomae in feed formula to increase growth and post larvae immunity of tiger shrimp Penaeus monodon Fab. to Vibrio harveyi infection. The Journal of Experimental Life Science 3: 31-36

[FAO] Food and Agriculture Organization of the United Nations. 2015. The state of world fisheries and aquaculture. FAO, Rome.

Fendjalang SNM, Budiardi T, Supriyono E, Effendi I. 2016. Production of vaname shrimp Litopenaeus vannamei on floating net with different spreed in Kepulauan Seribu Strait. Jurnal Ilmu dan Teknologi Kelautan Tropis 8: 201-214.

Ferreira GS, Bolívar NC, Pereira SA, Guertler C, Vieira FN, Mouriño JLP, Seiffert WQ. 2015. Microbial biofloc as source of probiotic bacteria for the culture of Litopenaeus vannamei. Aquaculture 448: 273-279.

Fry JP, Mailloux NA, Love DC, Milli MC, Cao L. 2018. Feed conversion efficiency in aquaculture: do we measure it correctly ?. Environmental Research Letter 13: 024017.

Furtado PS, Poersch LH, Wasielesky WJr. 2015. The effect of different alkalinity levels on Litopenaeus vannamei reared with biofloc technology (BFT). Aquaculture International 23: 345-358.

Haque MR, Islam MA, Wahab MA, Hoq ME, Rahman MM, Azim ME. 2016. Evaluation of production perfformance and profitability of hybrid red tilapia and genetically improved farmed tilapia (GIFT) strains in the carbon/ nitrogen controlled periphyton-based (C/ $\mathrm{N}$ - CP) on-farm prawn culture system in Bangladesh. Aquaculture Reports 4: 101-111.

Jhaa S, Raia S, Shresthaa M, Dianab JS, Mandala RB, Egna H. 2018. Production of periphyton to enhance yield in polyculture ponds with carps and small indigenous species. Aquaculture Reports 9: 74-81.

Kasnir M, Harlina, Rosmiati. 2014. Water quality parameter analysis for the feasibility of shrimp culture in Takalar Regency, Indonesia. Journal of Aquaculture Research \& Development 5: 1000273.

Kawamura G, Bagarinao TU, Yong ASK. 2017. Sensory systems and feeding behaviour of the giant freshwater prawn, Macrobrachium rosenbergii, and the marine whiteleg shrimp, Litopenaeus vannamei. Borneo Journal of Marine Science and Aquaculture 1: 80-91.

Kumar S, Anand PSS, Ravichandran P, Panigrahi A, Dayal JS, Raja RA, Deo AD, Ghoshal TK, Ponniah AG. 2015. Effect of periphyton on microbial dynamics, immune responses and growth performance in black tiger shrimp Penaeus monodon Fabricius, 1798. Indian Journal of Fisheries 62: 67-74.

Lebel L, Mungkung R, Gheewala SH, Lebel 
P. 2010. Innovation cycles, niches and sustainability in the shrimp aquaculture industry in Thailand. Environmental Science \& Policy 13: 291-302.

Lester SE, Stevens JM, Gentry RR, Kappel CV, Bell TW, Costello CJ, Gaines SD, Kiefer DA, Maue CC, Rensel JE, Simons RD, Washburn L, White C. 2018. Marine spatial planning makes room for offshore aquaculture in crowded coastal waters. Nature Communications 9: 945.

Luan S, Qiang G, Cao B, Luo K, Meng X, Chen B, Kong J. 2020. Feed competition reduces heritable variation for body weight in Litopenaeus vannamei. Genetic Selection Evolution 52: 45.

Martínez-Antonio EM, Racotta IS, RuvalcabaMárquez JC, Magallón-Barajas F. 2019. Modulation of stress response and productive performance of Litopenaeus vannamei through diet. PeerJ 6850.

Masud N, Ellison A, Cable J. 2019. A neglected fish stressor: mechanical disturbance during transportation impacts susceptibility to disease in a globally important ornamental fish. Diseases of Aquatic Organisms 134: 25-32.

Nagai C, Nagata S, Nagasawa H. 2011. Effects of crustacean hyperglycemic hormone $(\mathrm{CHH})$ on the transcript expression of carbohydrate metabolism-related enzyme genes in the kuruma prawn, Marsupenaeus japonicas. General and Comparative Endocrinology. 172: 293-304.

Novianti M, Widyorini N, Suprapto D. 2013. Analisis kelimpahan perifiton pada kerapatan lamun yang berbeda di perairan Pulau Panjang, Jepara. Journal of Management of Aquatic Resources 2: 219-225.

Pandey PK, Bharti V, Kumar K. 2014. Biofilm in aquaculture production. African Journal of Microbiology Research 8: 1434-1443.

Rana S. 2018. Specific growth rate and food conversion efficiency of freshwater crab Barytelphusa lugubris in Kathmandu, Nepal. International Journal of Zoology Studies 3: 53-57.

Sanchez-Jerez P, Karakassis I, Massa F, Fezzardi D, Aguilar-Manjarrez J, Soto D, Chapela R, Avila P, Macias JC, Tomassetti P, Marino G, Borg JA, Franiĉević V, Yucel-Gier G, Fleming IA, Biao X, Nhhala H, Hamza H, Forcada A, Dempster T. 2016. Aquaculture's struggle for space: the need for coastal spatial planning and the potential benefits of Allocated Zones for Aquaculture (AZAs) to avoid conflict and promote sustainability. Aquaculture Environment Interactions 8: 41-54.

Shields JD. 2019. Climate change enhances disease processes in crustaceans: case studies in lobsters, crabs, and shrimps. Journal of Crustacean Biology: 1-11.

Sudaryono A, Hasan M, Yusuf C. 2013. Analysis of traceability and sustainability of fish meal and fish oil on aquafeed industry in Indonesia. Aquacultura Indonesiana 14: 135-148.

Sudaryono A, Chilmawati D, Susilowati T. 2018. Oral administration of hot-water extract of tropical brown seaweed, Sargassum cristaefolium, to enhance immune response, stress tolerance, and resistance of white shrimp, Litopenaeus vannamei, to Vibrio parahaemolyticus. Journal of The World Aquaculture Society 49: 877-888.

Wang X, Li E, Chen L. 2016. A review of carbohydrate nutrition and metabolism in crustaceans. North American Journal of Aquaculture 78: 178-187.

Wang Z, Qu Y, Yan M, Li J, Zou J, Fan L. 2019. Physiological responses of Pacific white shrimp Litopenaeus vannamei to temperature fluctuation in low-salinity water. Frontiers in Physiology 10: 1025.

Yuslan A, Najuwa S, Hagiwara A, Ghaffar MA, Suhaimi H, Rasdi NW. 2021. Production performance of Moina macrocopa (Straus 1820) (crustacea, cladocera) cultured in different salinities: the effect on growth, survival, reproduction, and fatty acid composition of the neonates. Diversity 13: 105.

Zarain-Herzberg M, Campa-Córdova AI, Cavalli RO, 2006. Biological viability of producing white shrimp Litopenaeus vannamei in seawater floating cages. Aquaculture 259: 283-289.

Zarain-Herzberg M, Fraga I, HernandezLlamas A. 2010. Advances in intensifying the cultivation of the shrimp Litopenaeus vannamei in floating cages. Aquaculture 300: 87-92.

Zhang YS, Li FX, Yao CL. 2019. Glycogen phosphorylase of shrimp Litopenaeus vannamei: Structure, expression and anti-WSSV function. Fish and Shellfish Immunology 9: 275-283.

Zhao M, Yao D, Li S, Zhang Y, Aweya JJ. 2020. Effects of ammonia on shrimp physiology and immunity: a review. Reviews in Aquaculture: $1-18$ 